\title{
HUBUNGAN ANTARA KEMAMPUAN PERILAKU ASERTIF DENGAN KONDISI BULLYING ANAK USIA SEKOLAH
}

\author{
Dwinara Febrianti $^{1}$, Budi Anna Keliat ${ }^{2}$, Enie Novieastari ${ }^{3)}$ \\ ${ }^{1}$ *D III Keperawatan Fakultas Kesehatan Universitas MH Thamrin Jakarta Timur \\ ${ }^{2)}$ Fakultas Keperawatan Universitas Indonesia \\ sayantiara@gmail.com
}

\begin{abstract}
ABSTRAK
Bullying merupakan bagian dari tindakan agresif yang dilakukan berulangkali oleh seseorang yang memiliki kekuatan lebih terhadap anak yang lemah baik secara fisik maupun psikologis. Perilaku bullying cenderung memunculkan perilaku agresif. Berdasarkan survey sebelumnya dapat diestimasikan kejadian bullying pada anak sekolah dasar di Kota Depok adalah 31,8 $\%$. Tujuan bullying yaitu untuk mengetahui hubungan antara Kemampuan Perilaku Asertif Dengan Kondisi Bullying Anak Usia Sekolahdi kelurahan Depok Jaya. Metode yang biasanya dilakukan yaitu penelitian deskriptif dengan desain studi Cross Sectional. Responden penelitian ini sebanyak 76 orang. Analisis menggunakan Koeffisien Korelasi Pearson. Hasil penelitian menunjukan bahwa terdapat hubungan yang lemah antara kemampuan perilaku asertif dengan kondisi bullying yaitu - 0.145 dengan arah hubungan negatif (-) artinya semakin bertambahnya kemampuan perilaku asertif maka kondisi bullying akan semakin menurun. Hasil uji statistik menunjukan tidak ada hubungan yang signifikan antara kemampuan perilaku asertif dengan kondisi bullying pada kelompok yang mendapatkan latihan perilaku asertif. Kesimpulan Semakin bertambahnya kemampuan perilaku asertif maka kondisi bullying akan semakin menurun Walaupun tidak ada hubungan yang signifikan antara kemampuan perilaku asertif dengan kondisi bullying pada kelompok yang mendapatkan latihan perilaku asertif
\end{abstract}

Kata Kunci: Anak Usia Sekolah; Bullying, Kemampuan Perilaku Asertif

\section{PENDAHULUAN}

Perilaku agresif merupakan segala bentuk perilaku yang dimaksudkan untuk menyakiti seseorang baik secara fisik maupun mental, yang berdampak menyakiti baik bagi dirinya sendiri maupun orang lain. Perilaku agresif ini cenderung muncul secara mencolok pada masa kanak - kanak, bahkan dalam berinteraksi sosial anak sering memperlihatkan perilaku agresif seperti marah, bermusuhan, bertengkar, mengancam dan menghancurkan barang orang lain bahkan sampai dengan menyerang secara fisik, seiring bertambahnya usia, penyerangan fisik sudah mulai menurun, berganti dengan mengekspresikan marah secara tidak langsung melalui agresivitas verbal seperti mengejek teman, memberi julukan, perilaku menghindar dan penolakan. Bila kita melihat perilaku agresif merupakan perilaku negatif yang merugikan dan tidak diinginkan saat berinteraksi sosial tetapi hal tersebut bukanlah merupakan perilaku yang mudah untuk dihindari, bahkan sikap agresif ini terkadang digunakan sebagai bahan penggertak yang kuat bagi seseorang untuk mencapai keberhasilan (Tim Pustaka Familia, 2006). Perilaku agresif bila terus berlangsung terutama pada anak maka dapat menjadi suatu hal yang dianggap biasa untuk dilakukan, dapat mengakibatkan anak akankehilangan kepekaan terhadap perbuatan yang bisa membuat orang lain cedera (Berkowitz, 1984 dalam Surbakti, 2008) dan bila perilaku agresif dilakukan secara berulang dan menetap, maka perilaku tersebut dinamakan bullying yang saat ini banyak terjadi baik di dunia maupun di Indonesia.

Bullying merupakan bagian dari tindakan agresif yang dilakukan berulangkali olehseseorang/anak yang memiliki kekuatan lebih terhadap anak yang lemah baik secara fisik maupun psikologis (Astuti, 2008). Bullying merupakan fenomena yang sudah ada didunia sejak tahun 1970 diawali di Skandinavia dan menurut Rudi (2010) mulai beberapa tahun terakhir menjadi perhatian peneliti, pendidik, organisasi perlindungan dan tokoh 
masyarakat. Bully secara harfiah dalam bahasa Indonesia berarti penggertak, orang yang suka mengganggu yang lemah. Bila melihat dari kata tersebut terkadang perilaku bullying dianggap sebagai perilaku yang normal dalam kehidupan sehari-hari. Perilaku bullying merupakan "Learned Behaviour", suatu perilaku yang tidak bisa diterima secara sosial dan merupakan perilaku yang tidak normal dan tidak sehat (Rudi, 2010).

Kejadian bullying didunia pendidikan sudah banyak ditemukan baik diInternasional maupun di Indonesia. Menurut Gray dalam Parsons (2009) di Amerika Serikat terdapat 160.000 siswa tidak masuk sekolah setiap harinya karena masalah intimidasi. Institut Nasional tentang kesehatan anak dan perkembangan manusia di Amerika meneliti 15000 siswa dari kelas 6 sampai 1 SMA menunjukan 16\% siswa mengatakan pernah mengalami intimidasi oleh siswa lain. Beran dan Tutty (2005) menemukan setengah dari jumlah siswa dalam penelitiannya pernah mengalami intimidasi dan siswa kelas 1 sampai 3 diintimidasi sama seringnya dengan siswa kelas 4 sampai 6. Eron dalam penelitiannya lebih dari 30 tahun mengenai perilaku intimidasi menunjukan sebagian besar siswa yang dikenal sebagai pelaku intimidasi dikelas 3 sekolah dasar (SD) juga diidentifikasi sebagai pelaku intimidasi di tingkat akhir di SMA, dan pada usia tiga puluh, satu dari empat perilaku intimidasi memiliki catatan kriminal. Penelitian jangka panjang yang dilakukan di Kanada terhadap anak dan remaja menunjukan hubungan yang signifikan, 4100 anak dan orang tua ditelitipada tahun 1994-1995 saat anak berusia 2 dan 5 tahun, lalu diteliti kembali delapan tahun ke depan saat anak berusia 10 dan 13 tahun, ditemukan anak yang dibesarkan dengan pukulan, teriakan atau ancaman dirumah, delapan tahun kemudian ditemukan sebagai remaja yang sedikit agresif dan terlibat dalam perilaku intimidasi ataupun perkelahian di sekolah (Parson, 2009). Craig dan Peplar (1997) mengatakan beberapa studi longitudinal yang dilakukan lebih dari dua dekade telah menjelaskan perilaku bullying di sekolah dasar sebagai prekursor perilaku kekerasan, dan menunjukkan hubungan yang signifikan antara perilaku dan kegiatan kriminal dalam kehidupan dewasa (B.C. Safe School Centre., n.d).

Kejadian bullying sebenarnya sudah terjadi di sekolah dasar (SD) sebagai contohnya pada tanggal 15 Juli 2005 siswa SD yaitu Fifi, yang berusia 13 tahun yang melakukan tindakan bunuh diri karena merasa malu dan frustasi akibat sering diejek oleh teman-temannya (Wiyani, 2012). Berdasarkan hasil survey yang pernah dilakukan oleh Khairani (2006) yang melakukan survey terhadap kejadian bullying yang dilakukan pada dua sekolah dasar di Depok terhadap 95 siswa menunjukan hasil bahwa 31,8\% siswa pernah mengalami bullying, dan jenis yang paling banyak 77,3\% mengalami bullying nonverbal, 40,1\% mengalami bullying verbal dan 36,1\% mengalami bullying fisik. Berdasarkan survey bahwa anak yang berusia antara 9 sampai 13 tahun mengakui melakukan bullying (Borba, 2009). Melihat kejadian tersebut maka bullying memiliki dampak yang cukup serius bagi masa depan anak-anak upaya pencegahan bullying disekolah dapat dimulai dengan menciptakan budaya sekolah yang beratmosfer belajar tanpa rasa takut, melalui pendidikan karakter, menciptakan kebijakan pencegahan bullying disekolah dengan melibatkan siswa, menciptakan sekolah model penerapan sistem anti-bullying serta membangun kesadaran tentang bullying dan pencegahannya kepada stakesholders sampai ke lingkungan rumah (Astuti, 2008), sedangkan pendekatan yang dapat digunakan perawat adalah pendekatan terapi keperawatan, yaitu dengan pemberian terapi latihan perilaku asertif yang diharapkan anak akan mampu berperilaku asertif sehingga dapat mencegah atau mengatasi kondisi bullying. Perilaku asertif adalah perilaku interpersonal yang melibatkan kejujuran, keterbukaan dalam pikiran dan perasaan yang ditandai dengan kesesuaian sosial dan 
seseorang yang berperilaku asertif akan mempertimbangkan perasaan dan kesejahteraan orang lain (Gunarsa, 2007). Penelitian ini bertujuan untuk mengetahui hubungan antara Kemampuan Perilaku Asertif Dengan Kondisi Bullying Anak Usia Sekolah di kelurahan Depok Jaya.

\section{METODE}

Penelitian ini menggunakan jenis penelitian kuantitatif dengan desain penelitian Cross Sectional. Responden dalam penelitian ini adalah anak usia sekolah sebanyak 76 orang yang memenuhi kriteria inklusi. Kuisioner yang digunakan adalah Kuesioner kejadian bullying, untuk menggambarkan kondisi bullying pada anak sekolah dasar. Instrumen yang digunakan adalah "Peer interaction in primary school quesionare" yang dikembangkan oleh Tarshis.Kuisioner lainnya adalah adalah kemampuan anak usia sekolah tentang latihan perilaku asertif, instrumen ini untuk mengukur kemampuan anak usia sekolah terkait latihan perilaku asertif. Instrumen yang digunakan memodifikasi dari penelitian sebelumnya yaitu penelitian Tololiu, Keliat dan Daulima (2011). Variabel kemampuan perilaku asertif dan kondisi bullying merupakan data numerik, sehingga untuk mengetahui hubungan antara keduanya diuji dengan uji koefisien korelasi Pearson.

\section{HASIL}

Hasil penelitian tabel 1 menunjukan bahwa terdapat hubungan yang sedang antara kemampuan perilaku asertif dengan kondisi bullying pada kelompok anak usia sekolah, orangtua dan guru (intervensi 1) yaitu -0.264 dengan arah hubungan negatif (-) artinya semakin bertambahnya kemampuan perilaku asertif maka kondisi bullying akan semakin menurun. Hal ini menunjukan bahwa dengan keterlibatan orangtua dan guru memiliki peranan yang berarti dalam mempengaruhi kemampuan latihan perilaku asertif anak yang dapat menurunkan kondisi bullying. Sedangkan pada kelompok anak usia sekolah dan orangtua (intervensi 2) menunjukan terdapat hubungan yang lemah antara kemampuan perilaku asertif dengan kondisi bullying yaitu 0.017 dengan arah positif (+) artinya semakin bertambahnya kemampuan perilaku asertif maka kondisi bullying akan semakin tinggi. Ini menunjukan bahwa dengan hanya melibatkan orangtua saja belum bisa mempengaruhi kemampuan latihan perilaku asertif anak dalam mengatasi kondisi bullying dan kemungkinan lain pun bisa mempengaruhi hal ini seperti faktor lingkungan, faktor sosial budaya dan lain sebagainya yang memang memerlukan pembuktian lebih lanjut. Hasil uji statistik menunjukan tidak ada hubungan yang signifikan antara kemampuan perilaku asertif dengan kondisi bullying pada kelompok intervensi 1 maupun intervensi 2. Hasil Analisa menunjukan bahwa terdapat hubungan yang lemah antara kemampuan perilaku asertif dengan kondisi bullying yaitu -0.145 dengan arah hubungan negatif (-) artinya semakin bertambahnya kemampuan perilaku asertif maka kondisi bullying akan semakin menurun. Hasil uji statistik menunjukan tidak ada hubungan yang signifikan antara kemampuan perilaku asertif dengan kondisi bullying pada kelompok yang mendapatkan latihan perilaku asertif. Tidak adanya hubungan antara kemampuan perilaku asertif dengan kondisi bullying kemungkinan disebabkan oleh banyak faktor seperti faktor predisposisi dan faktor presipitasi yang sudah dijelaskan sebelumnya, dan untuk merubah perilaku seseorang memerlukan waktu yang cukup lama. Pada penelitian ini sudah menunjukan adanya perbedaan kemampuan perilaku asertif anak diantara kelompok yang diberikan terapi dengan kelompok yang tidak mendapatkan latihan perilaku asertif. Perilaku asertif adalah perilaku antar perorangan yang melibatkan aspek kejujuran dan keterbukaan pikiran dan perasaan, berani bertindak atas dasar 
minatnya dan prinsip hidupnya tanpa rasa takut ataupun cemas, dan menyampaikan haknya tanpa mengabaikan hak orang lain, tidak bersikap agresi atau menyerang hakorang lain. (Johnson, 2005; Gunarsa, 2007; Martono \& Joewana, 2008).

Tabel 1.

Hubungan Kemampuan Perilaku Asertif dengan Kondisi Bullying Anak Usia Sekolah pada Kelompok Intervensi di SDN Kelurahan Depok Jaya

\begin{tabular}{cclcc}
\hline Kelompok & N & \multicolumn{1}{c}{ Variabel } & R & P value \\
\hline Intervensi 1 & 40 & $\begin{array}{l}\text { Hubungan } \\
\text { kemampuan } \\
\text { perilaku asertif } \\
\text { dengan kondisi } \\
\text { bullying }\end{array}$ & -0.264 & 0.099 \\
\hline Intervensi 2 & 36 & $\begin{array}{l}\text { Hubungan } \\
\text { kemampuan } \\
\text { perilaku asertif } \\
\text { dengan kondisi } \\
\text { bullying }\end{array}$ & 0.017 & 0.922 \\
& & & \\
\hline
\end{tabular}

Tabel 2.

Hubungan Kemampuan Perilaku Asertif dengan Kondisi Bullying Anak Usia Sekolah pada Kelompok Intervensi di SDN Kelurahan Depok Jaya $(n=76)$

\begin{tabular}{|c|c|c|}
\hline Variabel & $\mathbf{R}$ & P value \\
\hline $\begin{array}{l}\text { Hubungan kemampuan } \\
\text { perilaku asertif dengan } \\
\text { kondisi bullying }\end{array}$ & -0.145 & 0.212 \\
\hline
\end{tabular}

\section{PEMBAHASAN}

Berdasarkan pengertian diatas dapat disimpulkan perilaku asertif adalah perilaku seseorang yang menyatakan perasaannya dengan jujur tanpa menyakiti atau melanggar hak orang lain. Ciri seseorang asertif menurut WHO (2003) yaitu menghormati diri sendiri sama dengan menghormati orang lain, menilai dengan tepat kebutuhan pribadi, keinginan, perasaan, mempertimbangkan kepentingan diri sendiri serta kepentingan orang lain, percaya diri dan sopan, mampu mengungkapkan pendapat dan bersedia mendengarkan orang lain, mengekspresikan perasaan positif sama dengan perasaan negatif, memperhatikan orang lain dan berani menuntut haknya, membela hak-hak orang lain tanpa mendominasi orang lain (Tololiu, Keliat \& Daulima, 2011). Ciri perilaku di atas dapat dijadikan pedoman untuk anak sekolah dasar agar mampu bersikap asertif dalam kehidupan seharihari dan dapat menghindari perilaku bullying National safety council (2004) mengatakan ada beberapa keterampilan asertif yang dapat digunakan yaitu: Belajar berkata "tidak", Belajar cara menggunakan pernyataan "Saya", menggunakan kontak mata, menggunakan bahasa tubuh yang asertif, melakukan penolakan secara damai, menghindari manipulasi dan mencoba berespon bukan bereaksi. Bila melihat pendapat diatas maka kemungkinan tidak adanya hubungan antara kemampuan perilaku asertif dengan kondisi bullying pada penelitian ini karena melihat penerapan latihan perilaku asertif lebih mengarah pada tehnik-tehnik pencegahan terjadinya bullying dan juga dipengaruhi oleh waktu yang terlalu singkat dalam pelaksanaan terapi, dan tidak ada hubungan antara kemampuan perilaku asertif dengan kondisi bullying kemungkinan karena untuk merubah perilaku seseorang setelah diberikan latihan memerlukan proses belajar yang cukup lama seperti yang diungkapkan oleh Notoatmodjo (2012) bahwa hasil atau perubahan perilaku setelah diberikan edukasi akan 
memakan waktu yang lama, tetapi perubahan yang dicapai akan bersifat langgeng karena didasari oleh kesadaran mereka sendiri bukan karena paksaan.

Anak - anak dengan kondisi bullying kemungkinan memiliki kekurangan dalam keterampilan sosial seperti pendapat Sutton et al. (1999) dalam Larke (2004) bahwa anak-anak yang agresif mungkin memiliki kekurangan dalam sosial dan dalam penelitiannya Larke (2004) menunjukkan hubungan yang signifikan antara bullying fisik langsung dengan keterampilan sosial $(\mathrm{r}=-0,46 \mathrm{p}<0.01)$, dan bullying tidak langsung dengan keterampilan sosial $(r=-0.26 \mathrm{p}<0.01)$. Pelatihan keterampilan sosial (SST) adalah intervensi yang telah diusulkan sebagai solusi yang mungkin untuk meningkatkan kompetensi sosial dan, mengurangi risiko terjadi anak isolasi sosial dan risiko menjadi korban bullying (Hancock, 2007). Bila dilihat dari observasi selama latihan perilaku asertif maka untuk memudah anak usia sekolah dalam menurunkan kondisi bullying maka dapat menggabungkan latihan perilaku asertif dengan social skill training.

\section{KESIMPULAN DAN REKOMENDASI}

Semakin bertambahnya kemampuan perilaku asertif maka kondisi bullying akan semakin menurun Walaupun tidak ada hubungan yang signifikan antara kemampuan perilaku asertif dengan kondisi bullying pada kelompok yang mendapatkan latihan perilaku asertif.

Penelitian selanjutnya sebaiknya memperhatikan faktor predisposisi dan presipitasi, memberikan latihan lebih dari 2 minggu sebagai pembudayaan dan menggabungkan latihan asertif dengan sosial skill terapi serta memperhatikan faktor yang berkontribusi.

\section{REFERENSI}

1. Astuti, P. R. (2008). Meredam Bullying: 3 cara efektif mengatasai kekerasan pada anak. Jakarta: Grasindo B.C. Safe School Centre. (n.d). Focus on bullying: A prevention program for elementary School communities. Columbia: British Columbia.

2. Borba, M. (2010). The big book of parenting solutions. (Juliska Grasinia \&Yanuarita Fitriyani, penerjemah). Jakarta: PT.Elex Media Komputindo

3. Gunarsa, S. (2007). Konseling dan psikoterapi. Jakarta: Gunung Mulia

4. Hamid, A.Y. (2009). Bunga rampai asuhan keperawatan kesehatan jiwa. Jakarta:EGC

5. Hancock, Kyle Max. (2007). Social Interactions And Bullying In Withdrawn Children:An Evaluation Of Generalization Strategies Within A Social Skills Training Intervention. ProQuest Information and Learning Company

6. Hastono, S.P. \& Sabri Luknis. (2010). Statistik kesehatan. Jakarta: PT Raja Grafindo Persada.

7. Johnson, J.Y., Temple, J.S., \& Carr, P. (2005). Prosedur perawatan di rumah:Pedoman untuk perawat. (Monica Ester, Penerjemah). Jakarta: EGC

8. Larke Ian Douglas. (2004). The Relationship between Bullying and Social Skills in Elementary School Student. ProQuest Dissertations \& Theses (PQDT).

9. Martono, L.H. \& Joewana, S. (2008). Belajar hidup bertanggung jawab,menangkal narkoba dan kekerasan. Jakarta: Balai Pustaka.

10. National Safety Council. (2004). Manajemen stress. (Palupi Widyastuti,penerjemah). Jakarta: EGC 
11. Notoatmodjo. S. (2012). Ilmu perilaku kesehatan. Jakarta: PT Rineka Cipta

12. Parsons, L. (2009). Bullied teacher bullied student. (Grace Worang,Penerjemah). Jakarta: PT Grasindo.

13. Rudi, T. (2010). Informasi perihal bullying. 8 Januari 2013. bigloveadagio.files.wordpress.com/.../informasi_perihal_bullying.pdf

14. Surbakti, E.B. (2008). Awas tayangan televisi: tayangan misteri dan kekerasan mengancam anak anda. Jakarta: PT Elex Media Komputindo.

15. Susana, S.A. \& Hendarsih, S. (2012). Terapi modalitas: Keperawatan kesehatan jiwa. Jakarta: EGC

16. Tim Pustaka Familia. (2006). Menyikapi perilaku agresif anak. Jokjakarta: Penerbit Kanisiu

17. Tololiu, T., Keliat, B.A., \& Daulima, N. H. C (2011). An effective assertive behaviour training in avoiding bullying to adolescent at Depok, Indonesia.Journal of Psychosocial Nursing \& Mental Health Services

18. Walter, Keliat, B.A, \& Sunarto, M. (2012). Buku saku terapi spesialis keperawatan jiwa. Depok: FIK UI 